\title{
Commentary: new development goals must focus on social determinants of health
}

\author{
David Legge scholar emeritus ${ }^{1}$, David Sanders emeritus professor ${ }^{2}$ \\ ${ }^{1}$ La Trobe University, Melbourne VIC 3086, Australia; ${ }^{2}$ School of Public Health, University of the Western Cape, Belville, South Africa
}

\begin{abstract}
Although the millennium development goals (MDGs) addressed some of the starkest manifestations of the contemporary global health crisis, they failed to confront the underlying structures that maintain the crisis, including globalisation. In reflecting on the post-2015 development agenda, ${ }^{1}$ we need to challenge some key assumptions about the genesis and effect of the current goals.

Much of the discourse around the MDGs since 2000 has suggested that attainment would be secured by creating a global partnership for development (goal 8) and would require "more of the same," including increased development assistance. An alternative interpretation is that both the goals and the increased development assistance since 2000 were motivated, at least in part, by the need to shore up the legitimacy of what was increasingly seen as an inequitable and unsustainable economic regime. The goals were adopted in the context of powerful civil society campaigns around debt relief and access to treatment - campaigns that challenged the legitimacy of the International Monetary Fund's structural adjustment policies and the restrictive provisions of the international agreement on trade related intellectual property rights (TRIPS). The weight of the challenge to economic globalisation is shown by the fact that the World Trade Organisation's 2001 Doha Declaration included reassurances that trade agreements should not over-ride public health objectives. ${ }^{2}$
\end{abstract}

We also need to re-evaluate the assumption that increased development assistance has contributed to meaningful social and economic development. While there have been improvements in some of the global health indicators, the averages disguise wide inequalities in many countries, both rich and poor $^{34}$; there are large populations that have experienced little or no improvement. In some countries increased aid has enhanced access to treatment, but healthcare based on donor funding is neither secure nor sustainable.

\section{New approach}

As well as the health crisis (untreated AIDS, escalating tuberculosis, avoidable child and maternal deaths), humanity faces a more complex set of global crises, including global warming, financial instability, food insecurity, an unsustainable population, and environmental degradation. These crises are all underpinned by structured inequalities and an unsustainable economic system. If we are to exercise intentional control over this unbalanced runaway system the structures and norms of national and global governance, including of trade and financial markets, need reform.

The United Nations Development Programme states that the central goal of human development is "providing opportunities and choices for all." ${ }^{\circ}$ This must involve building the institutions and systems that give communities control over their futures: in Sen's terms, the freedom to choose how they will live. ${ }^{6}$ Development must include, but go well beyond, aid.

The People's Health Movement has argued that the post-2015 development agenda will need to confront the underlying dynamics that are driving widening inequality, creating avoidable suffering, and accelerating global warming. ${ }^{7}$ We need to confront and change the structural determinants of ill health and malnutrition. ${ }^{89}$ This will include regulating transnational corporations, especially in banking, agriculture, food, and pharmaceuticals. Universal health coverage is a priority but it should be clearly defined as including equitable access to quality care and strengthening public health systems.

Consensus on these issues is a long way off, and a critical item on the post-2015 development agenda will be to cultivate new modes of dialogue between deeply divergent interests across different countries, constituencies, and corporations. Such reconciliation and consensus building will require inspiring leadership, participatory policy development, and (as with the impetus behind the original MDGs) continuing mobilisation of civil society—not just international financial assistance.

Competing interests: We have read and understood the BMJ Group policy on declaration of interests and declare we are members of the steering council of the People's Health Movement.

Provenance and peer review: Commissioned; not externally peer reviewed.

Kenny C. What should follow the millennium development goals? BMJ 2013;346:f1193. World Trade Organisation Ministerial Council. Doha ministerial declaration. 2001. www. wto.org/english/thewto_e/minist_e/min01_e/mindecl_e.htm. 
3 Moser KA, Leon DA, Gwatkin DR. How does progress towards the child mortality millennium development goal affect inequalities between the poorest and least poor? Analysis of Demographic and Health Survey data. BMJ 2005;331:1180.

4 Gwatkin DR. How much would poor people gain from faster progress towards the millennium development goals for health? Lancet 2005;365:813-7.

5 UN Development Programme. Human development report 2011: sustainability and equity: a better future for all. 2011. www.undp.org/content/dam/undp/library/corporate/HDR/ 2011\%20Global\%20HDR/English/HDR_2011_EN_Complete.pdf .

6 Sen A. Development as freedom. Oxford University Press, 1999.
7 People's Health Movement. Health in the post-2015 development agenda. www. phmovement.org/sites/www.phmovement.org/files/PHM\%20statement\%20submitted\% phmovement.org/sites/ww w.

8 Friel S, Labonte R, Sanders D. Measuring progress on diet-related NCDs: the need to address the causes of the causes. Lancet 2013;381:903-4.

9 Commission on Social Determinants of Health. Closing the gap in a generation: health equity through action on the social determinants of health. WHO, 2008.

Cite this as: BMJ 2013:346:f1893

(c) BMJ Publishing Group Ltd 2013 